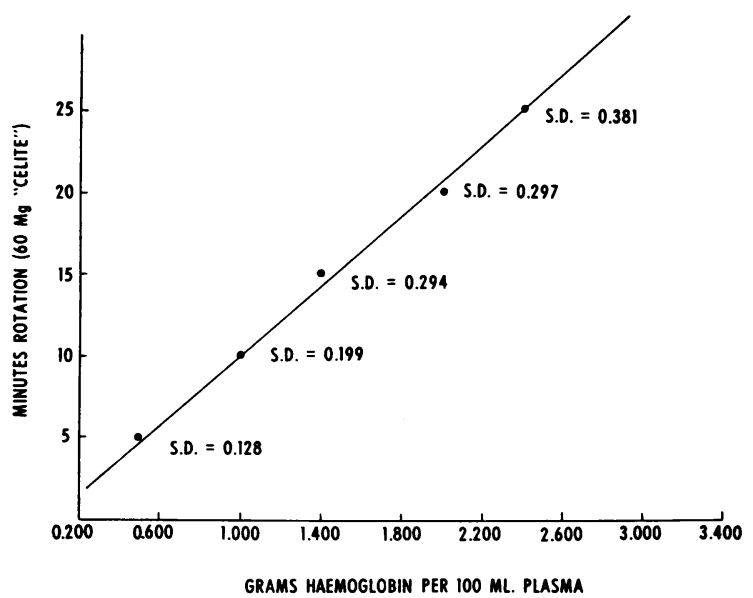

FIG. 2. Plasma haemoglobin in samples of normal human blood.

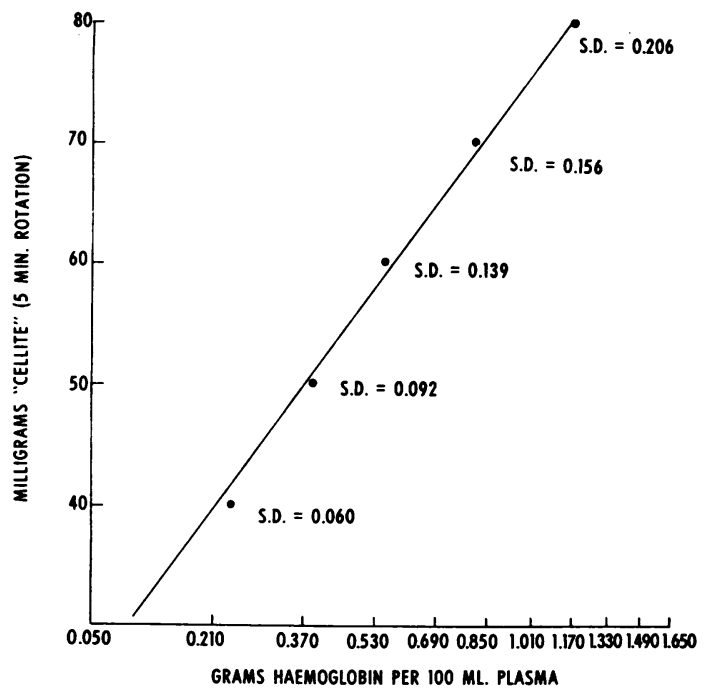

FIG. 3. Plasma haemoglobin in 19 samples of normal blood.

haemoglobin $(\mathrm{g} / 100 \mathrm{ml})$ of the control tube from the haemoglobin $(\mathrm{g} / 100 \mathrm{ml})$ of the rotated tube.

Figures 2 and 3 show the effect of varying the time of rotation or concentration of Celite on the haemoglobin released from samples of normal human blood. In Table I the erythrocyte fragility of samples of normal human blood is recorded. Human subject R.K. (Table II), studied on four different occasions, revealed small variations in erythrocyte fragility.

The amount of blood or Celite and the time of rotation can be varied to improve the degree of precision and to suit the convenience of the laboratory.

This work was supported by USPHS grant no. HE-07181. We are indebted to the Pathology Department of the University of Missouri for technical assistance. REFERENCE

Drabkin, D. L., and J. H. Austin (1935). J. biol. Chem., 112. 51.

\section{Differentiation of foetal and maternal erythrocytes in formol-fixed tissues}

\author{
C. G. PAINE From the Department of Pathology, \\ Jessop Hospital for Women, Sheffield
}

The elution techniques of Kleihauer, Hildegard, and Betke (1957) and of Singer, Chernoff, and Singer (1951), as applied to peripheral maternal blood, have provided valuable methods for determining the severity of transplacental bleeding. Their application to formol-fixed tissues has not proved successful in demonstrating the sites of admixture of the foetal and maternal circulations. A differential destruction technique applicable to formol-fixed placental tissue is therefore described.

\section{MATERIALS AND METHOD}

Full-term placentae were fixed whole in $10 \%$ formol saline for four days before representative blocks were cut for section. Tissues were processed in the normal way for paraffin sections and cut at $5 \mu$. Sections were dewaxed and taken through to water. They were then exposed at $37^{\circ} \mathrm{C}$ to peptic digestion in an acid buffer solution. After washing in water for 10 minutes, they were then stained by Erhlich's haematoxylin and alcoholic eosin.

\section{SOLUTIONS}

1 Pepsin (BPC) 25 units per $\mathrm{ml}$ in distilled water 2 Glycine buffer
A Glycine ..................7.505 g
$\mathrm{NaCl} \ldots \ldots \ldots \ldots \ldots \ldots \ldots \ldots \ldots .85 \mathrm{~g}$
Distilled water to 1 litre
B $\quad 0 \cdot 1 \mathrm{~N} \mathrm{HCl}$

Thirty-eight $\mathrm{ml}$ Solution A and $62 \mathrm{ml}$ Solution B provided a buffer solution at $p \mathrm{H} 1 \cdot 8$.

Sections were incubated at $37^{\circ} \mathrm{C}$ for varying periods in petri dishes containing $1.25 \mathrm{ml}$ pepsin solution and $5.0 \mathrm{ml}$ buffer solution, the final concentration of pepsin being 5 units $/ \mathrm{ml}$.

\section{RESULTS}

Incubation for periods in excess of 10 minutes resulted in complete destruction of both foetal and maternal erythrocytes. Destruction of maternal red cells was seen to start after four minutes' incubation and was complete after eight minutes. Destruction of foetal red cells was not appreciable until after eight minutes' incubation. At eight minutes a clear distinction between the two types of cell was demonstrable (Figs. 1 and 2). Little change was seen in the histological detail of the remaining tissue even after $\mathbf{4 0}$ minutes' incubation.

Received for publication 7 February 1968. 


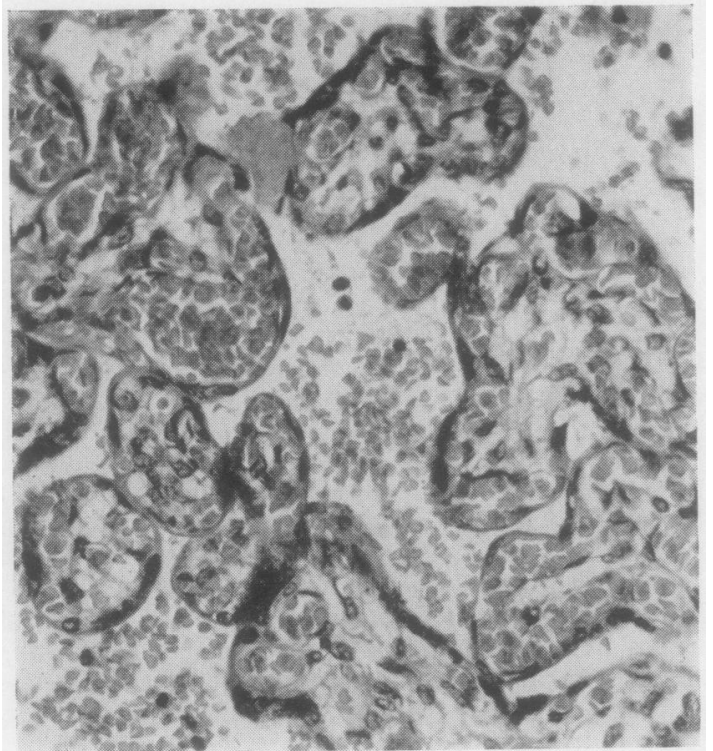

FIG. 1. Normal full-term placental tissue to show distribution of maternal and foetal erythrocytes. Haematoxylin and eosin $\times 400$.

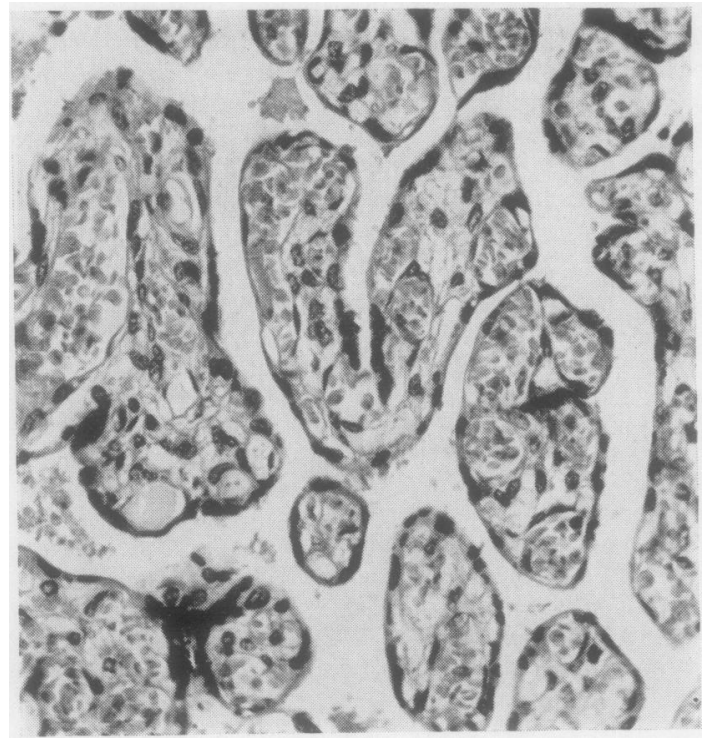

FIG. 2. Normal full term placental tissue, after eight minutes' peptic digestion to show survival of foetal red cells within the villous capillaries. Haematoxylin and eosin $\times 400$.

\section{REFERENCES}

Kleihauer, E., Hildegard, B., and Betke, K. (1957). Klin. Wschr., 35, 637.

Singer K., Chernoff, A. I., and Singer, L. (1951). Blood, 6, 413.

\section{Mechanical rotary device for} plating out bacteria on solid medium

R. FRASER WILLIAMS AND JENNIFER M. BAMBURY From the Department of Medical Microbiology, St. Thomas's Hospital Medical School, London

Most clinical bacteriological investigations start with streaking or plating out of material containing bacteria $\vec{\omega}$ on to the surface of solid medium so that isolated colonies appear during incubation. Further plating of $\overline{0}$ single colonies may be necessary to ensure purity of the is culture, or to obtain larger amounts of the bacterium $\vec{\sigma}$ under study. Plating is usually carried out by streaking inoculum on to agar in such a way that a progressive surface dilution is obtained. Conventionally, sterilized $\mathrm{O}$ wire loops, mounted in metal handles, are used for this purpose, though some workers favour the use of glass rods with rounded ends.

Whatever method is used, plating out is tedious and a $\overleftarrow{\Phi}$ time-consuming process, and may absorb a major pro- $\bar{\partial}$ portion of the work of a busy laboratory; this article $\mathbb{D}$ describes a mechanical device designed to eliminate much of the tedium and fatigue associated with the procedure.

\section{DESCRIPTION OF THE MACHINE}

The rotary plater is essentially an electrically driven horizontal circular metal turntable with a raised lip $\frac{\mathrm{D}}{\mathrm{D}}$ around the circumference. This is mounted on a central $\varrho$ spindle, grooved at the end to fit on to a shaft in the $\overrightarrow{\overrightarrow{0}}$ motor so that the turntable can easily be detached and $\frac{0}{3}$ replaced for cleaning and sterilizing. Turntables of $\supset$ different diameters can be used to accommodate various sizes of petri dish.

The rotary unit is powered by a shaded-pole motor $\overrightarrow{\bar{O}}$ with 90 milliamps output and 20 Watts consumption 0 which drives a heavy-duty gear base at a constant speed 3 of 58 revolutions per minute, and this is mounted in a $\bar{\rho}$ stove-enamelled metal case fitted with a switch and red $\frac{0}{3}$ warning light. There are 6 feet of flex and the unit is $\mathrm{O}$ suitable for $200 / 250$ volt main operation.

\section{MODE OF OPERATION AND USES}

An open petri dish is placed on the rotating turntable and the wire loop loaded by touching a colony; the user sits 0 with one or both elbows resting on the bench top beside the machine and the loop handle is held so that the wire 0 points towards the operator. The loop is lowered to touch the circumferential surface of the agar nearest to the operator and, as the dish rotates, it is drawn radially to $\$$ the centre of the plate and lifted off. In this way, a spiral ${ }^{-}$ track is covered by the loop, and the distance between $\bar{T}$ the coils of the spiral can be varied by increasing or $\frac{O}{\mathbb{D}}$ diminishing the rate of radial traverse. As the loop moves

Received for publication 20 February 1968.

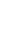

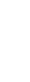

